reports have emphasised the severity of neurological and systemic disorder in patients with toxocaral meningoencephalitis. ${ }^{12} 4$ Apart from neck stiffness our patient was surprisingly well with no evidence of encephalitis. Her diagnosis might have been that of an atypical viral meningitis had Romanovsky staining not been performed. We think that this investigation may be useful in culture negative meningitis when there are no signs of viral infection.

Toxocara enzyme linked immunosorbent assay titres using $T$ canis excretory-secretory products as antigen

\begin{tabular}{|c|c|c|}
\hline & Acute serum & Convalescent serum \\
\hline $\begin{array}{l}\mathrm{IgG} \\
\mathrm{IgE}\end{array}$ & $\begin{array}{l}1 / 400 \\
1 / 320\end{array}$ & $\begin{array}{l}1 / 200 \\
1 / 320\end{array}$ \\
\hline \multicolumn{3}{|c|}{ Anti-A agglutinins: } \\
\hline $\operatorname{Ig} M\left\{\begin{array}{l}A_{1} \\
A_{2}\end{array}\right.$ & $\begin{array}{l}1 / 16 \\
1 / 8\end{array}$ & $\begin{array}{l}1 / 16 \\
1 / 8\end{array}$ \\
\hline $\mathrm{IgG}\left\{\begin{array}{l}\mathrm{A}_{1} \\
\mathrm{~A}_{2}\end{array}\right.$ & $\begin{array}{l}1 / 8192 \\
1 / 8192\end{array}$ & $\begin{array}{l}1 / 4096 \\
1 / 2048\end{array}$ \\
\hline
\end{tabular}

Note: erythrocytes $0^{+}$.

We decided to give specific antitoxocaral treatment because of the risk of ocular lesions or recurrence in the central nervous system, ${ }^{1}$ although there is little evidence for the efficacy of diethylcarbamazine or thiabendazole ${ }^{12}$ and there is the risk of release of larval antigen and reaction to this.

This is the first reported case of a mild, self limiting eosinophilic meningitis due to Toxocara canis, but overt manifestations of toxocaral infection are uncommon in Britain. It is interesting to speculate how common this presentation of toxocariasis may be in view of the fact that over $2 \%$ of the population in Britain have seroconverted. ${ }^{5}$

Thanks are due to Drs R W A Girdwood and H V Smith, of the Scottish Parasite Reference Laboratory, for helpful advice and for performing the assays and to Mrs D Hammond for typing the manuscript.

1 Schantz PM, Glickman LT. Toxocaral visceral larva migrans. $N$ Engl f Med 1978;298:436-9.

Bell WE, McCormick WF. Neurologic infections in childhood. 2nd ed. Philadelphia:

W B Saunders Company, $1981: 572-6$.
Bosch I, Oehmichen M. Eosinophilic granulocytes in cerebrospinal fluid: analysis of 94 cerebrospinal fluid specimens and review of the literature. $\dot{f}$ Neurol

4 Schochet SS. Human Toxocara canis encephalopathy in a case of visceral larva 5 Woodruff AW. Toxocariasis. Br Med f 1970; iii :663-9.

(Accepted 19 fuly 1985)

Departments of Microbiology and Paediatric Neurology, The Children's Hospital, Birmingham

I M GOULD, MRCP, senior registrar in microbiology

S NEWELL, MRCP, registrar

S H GREEN, MRCP, consultant paediatrician

R H GEORGE, MRCPATH, consultant medical microbiologist

Correspondence to: Dr I M Gould, Department of Medical Microbiology, Dudley Road Hospital, Birmingham B18 7QH.

\section{Size of pancreas in diabetes mellitus: a study based on ultrasound}

We have shown that exocrine pancreatic deficit is common in diabetes and that the degree of this deficit parallels the endocrine deficit. ${ }^{1-4}$ From necropsy data we also know that the size of the pancreas in patients with insulin dependent diabetes is smaller than in normal people. ${ }^{5}$ In order to confirm this observation in insulin dependent diabetes ${ }^{5}$ and to determine whether pancreatic size is also altered in non-insulin dependent diabetes mellitus we studied the pancreatic size in patients with diabetes mellitus using ultrasound techniques.

\section{Patients, methods, and results}

Sixty adult diabetic patients were investigated : 22 had insulin dependent diabetes (group 1) and 19 non-insulin dependent diabetes (group 2) and 19 were non-ketotic patients who had to be given insulin because of inadequacy of diabetic control with oral hypoglycaemic agents (group 3). Nineteen healthy controls were also studied.
All scans were performed by one of us (LAB), using a real time linear array system (Picker LS 3000).

The patients and controls were scanned in the morning after an overnight fast. Scans were performed with the patients supine and erect. A more complete and clearer visualisation of the pancreas was achieved by scanning with the patient erect. The head (defined as the area medial to the superior mesenteric vein) and the body of the pancreas were measured separately, since these were often visualised to best advantage in different views. As the head is often oriented in the longitudinal plane parallel to the inferior vena cava, measurements were made in this plane below the portal vein as well as in the transverse or oblique plane (taking the midpoint of the confluence of the superior mesenteric and splenic veins as the marker point). In normal subjects the longitudinal section of the head was frequently larger than the transverse sections. This did not occur in any of the diabetic patients. The tail of the pancreas was well seen as it passed anterior to the left kidney, but the more distal portion extending into the splenic hilum (which represents a very small part of the pancreatic mass) was rarely seen.

The scans were recorded on photographic paper. The outline of the pancreas was mapped out and the areas computed using a Numonics Graphic Analyzer (Numonics, Japan)

Both the head and the body of the pancreas in patients of group 1 and 2 were noticeably smaller than in the controls (table). The head and body of the pancreas in patients of group 2 were significantly larger than in group 1 .

Total area of pancreas and area of head and body of pancreas (in $\left.\mathrm{cm}^{2}\right)$ in diabetic patients and controls. Values are medians (ranges in parentheses)

\begin{tabular}{|c|c|c|c|c|}
\hline Group & $\begin{array}{l}\text { No of } \\
\text { subjects }\end{array}$ & Total area & Area of head & Area of body \\
\hline $\begin{array}{l}1 \\
2 \\
3 \\
\text { Controls }\end{array}$ & $\begin{array}{l}22 \\
19 \\
19 \\
19\end{array}$ & $\begin{array}{c}8 \cdot 9^{*}+(4 \cdot 6-14 \cdot 7) \\
12 \cdot 9 \ddagger(6 \cdot 6-17 \cdot 8) \\
11 \cdot 9 \ddagger(6 \cdot 7-17 \cdot 3) \\
18 \cdot 7^{+}(13 \cdot 0-26 \cdot 1)\end{array}$ & $\begin{array}{l}3 \cdot 2 * \dagger(1 \cdot 1-5 \cdot 7) \\
5 \cdot 7 \pm(2 \cdot 2-11 \cdot 8) \\
4 \cdot 8+(2 \cdot 5-6 \cdot 4) \\
8 \cdot 8(6 \cdot 2-11 \cdot 1)\end{array}$ & $\begin{array}{c}5 \cdot 7 * \S(2 \cdot 0-11 \cdot 2) \\
7 \cdot 8 \pm(4 \cdot 4-11 \cdot 8) \\
6 \cdot 7 \ddagger(3 \cdot 4-13 \cdot 6) \\
10 \cdot 4(7 \cdot 1-19 \cdot 8)\end{array}$ \\
\hline
\end{tabular}

*Compared with controls $\mathrm{p}<0.001$.

Compared with controls $\mathrm{p}<0.001$.
+Compared with group $2 \mathrm{p}<0.002$.
tCompared with controls $\mathrm{p}<0.002$.

Compared with controls $\mathrm{p}<0.002$.
\&Compared with group $2 \mathrm{p}<0.05$.

In group 3 the sizes of the head and body of the pancreas were intermediate between those in groups 1 and 2 .

There was no correlation between size of the pancreas and body weight or duration of diabetes.

\section{Comment}

These results show that the pancreas is significantly smaller in diabetic patients than in healthy controls. Furthermore, patients with insulin dependent diabetes have significantly smaller pancreases than patients with non-insulin dependent disease. Non-ketotic patients whose diabetes was not controlled with maximum doses of oral hypoglycaemic agents and who required insulin had pancreases intermediate in size between those in the other two groups. This is the first study to document these changes systematically. The pattern of diminution in the size of the pancreas in diabetes parallels the impairment of exocrine function previously described by us. Thus patients with insulin dependent diabetes have the lowest serum concentrations of pancreatic enzymes. Patients with non-insulin dependent disease have marginally reduced serum pancreatic enzyme values, while patients with non-ketotic disease who require insulin because of inadequate control with oral hypoglycaemic agents have serum pancreatic enzyme values between those of the other two groups. ${ }^{1-4}$

Pancreatic enzyme values at the time of clinical onset of insulin dependent diabetes mellitus indicate that in these patients exocrine pancreatic reserve may be diminished at the time of presentation, suggesting that exocrine damage occurs not as a long term complication of and sequel to diabetes but probably as a consequence of the process which caused the pancreatic islet and $\beta$ cell damage. ${ }^{4}$ The factors responsible for the shrinkage of pancreas through a reduction of exocrine tissue may be immunological (lymphocytic infiltration has been observed); genetic; subclinical viral pancreatitis; or lack of trophic effect of insulin on exocrine pancreas. The last is particularly relevant to non-insulin dependent diabetes.

We thank Pamela Dale for secretarial work and Georgina Gray and Rita Stavrou for their help.

Dandona $\mathrm{P}$, Elias E, Beckett AG. Serum trypsin concentrations in diabetes mellitus. Br Med 7 1978;ii:1125-7.

Foo $\mathrm{Y}$, Rosalki SB, Ramdial Likhailidis $D$, Dandona $P$ Serum isoamylase concentrations in diabetes mellitus. F Clin Pathol 1980;33:1 102-5. Junglee D, de Albarran R, Katrak A, Freedman D, Beckett AG, Dandona P. Pancreatic lipase concentration in diabetes mellitus. $f$ Clin Pathol $1983 ; 36: 200-2$.
Dandona P, Freedman DB, Foo Y, et al. Exocrine pancreatic function in diabetes mellitus. ' $\mathrm{f}$ Clin Pathol $1984 ; 37: 302-6$. .

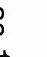
\title{
.
}

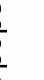

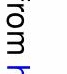

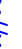

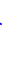
N \section{O
D
0} \section{.}


5 Le Compte PM, Gepts W. The pathology of juvenile diabetes. In: Volk BW, Wellman KF, eds. The diabetic pancreas. New York: Plenum Press, 1977: 325-53.

(Accepted 25 fuly 1985)

Departments of Chemical Pathology and Human Metabolism and Radiology, Royal Free Hospital and School of Medicine, London

V FONSECA, MD, MRCP, research fellow

L A BERGER, FRCR, FFR, consultant radiologist

A G BECKETT, FRCP, consultant physician

P DANDONA, DPHIL, MRCP, director of metabolic unit

Correspondence to: Dr P Dandona, Department of Chemical Pathology and Human Metabolism, Royal Free Hospital, London NW3 2QG.

\section{$\alpha$ Atrial natriuretic peptide concentrations in plasma of children with congenital heart and pulmonary diseases}

Three peptides have recently been isolated from mammalian atrial myocytes, all of which have natriuretic, diuretic, and hypotensive activity. In man the smallest of these, $\alpha$ human atrial natriuretic peptide, comprises 28 amino acids.

Studies in animals suggest that the peptides are released from the atria in response to increased atrial pressure. ${ }^{2} \mathrm{~A}$ similar mechanism might play a part in controlling the release of $\alpha$ human atrial natriuretic peptide from the human heart. To test this hypothesis we measured the plasma concentrations of $\alpha$ human atrial natriuretic peptide in children with various types of congenital heart disease and bronchopulmonary dysplasia, which are known to be associated with high atrial pressure and atrial stretching.

\section{Patients, methods, and results}

Four children with bronchopulmonary dysplasia, Northway stage IV ${ }^{\prime}$ aged 17-27 months and 10 children with congenital heart diseases aged 1 month to 15 years were studied. The mean gestational age and birth weight of the children with bronchopulmonary disease was 32 weeks and $1580 \mathrm{~g}$, respectively. Among the patients with cardiac disease there were three cases of Fallot's tetralogy (one after surgical reconstruction) and one each of patent ductus arteriosus, transposition of the great arteries, ventricular septal defect, and coarctation of the aorta, tricuspid atresia, ventricular septal defect, mitral stenosis, and cardiomyopathy. All diagnoses were made on the basis of $x$ ray findings, two dimensional echocardiography, or cardiac catheterisation. None of the children had a history of any other disease known to affect water balance. The patients with bronchopulmonary dysplasia were treated with diuretics and digoxin. Four children with congenital heart disease were treated with digoxin and frusemide.

The control group consisted of 51 children ( 24 boys, 27 girls) who had been admitted to hospital aged 1 month to 16 years with endocrine disorders such as delayed puberty, retardation of growth, and obesity or who were recovering from infectious diseases or minor surgery. Children suffering from cardiac and bronchopulmonary diseases and those with disorders affecting the fluid and electrolyte balance were excluded.

Blood samples were taken for measurement of $\alpha$ human atrial natriuretic peptide concentrations from peripheral veins during routine sampling between 8 am and 11 am with patients supine. Concentrations of $\alpha$ human atrial natriuretic peptide were measured by radioimmunoassay as described above. ${ }^{3}$

The mean concentration of $\alpha$ human atrial natriuretic peptide in the control group was $27 \mathrm{fmol} / \mathrm{ml}$ (range $1-45.5 \mathrm{fmol} / \mathrm{ml}(3-136.5 \mathrm{pg} / \mathrm{ml}$ )) (figure). The mean plasma concentration in children under 1 year of age did not differ significantly from that of children older than 1 . By contrast, concentrations up to 10 times higher were found in the group of children with congenital heart or bronchopulmonary diseases. An overlap with the upper range of the concentrations of $\alpha$ human atrial natriuretic peptide in the control group was observed in the one patient who had undergone surgical reconstruction of Fallot's tetralogy.

\section{Comment}

It has recently been reported that $\alpha$ human atrial natriuretic peptide, when given as an intravenous bolus to healthy subjects, increased urinary sodium excretion and urine volume and immediately decreased blood pressure, probably owing to vasodilatation. ${ }^{45}$ This observation together with the fact that $\alpha$ human atrial natriuretic peptide is a hormone circulating in the blood implies that the cardiac atria are one site where the volume of vascular fluid is regulated. The increased concentrations of $\alpha$ human atrial natriuretic peptide in the plasma of children with cardiopulmonary disorders probably reflect the heart's attempt to counteract excessive volume or pressure by reducing plasma volume, peripheral resistance, and venous return. The concentration of circulating $\alpha$ human atrial natriuretic peptide observed in

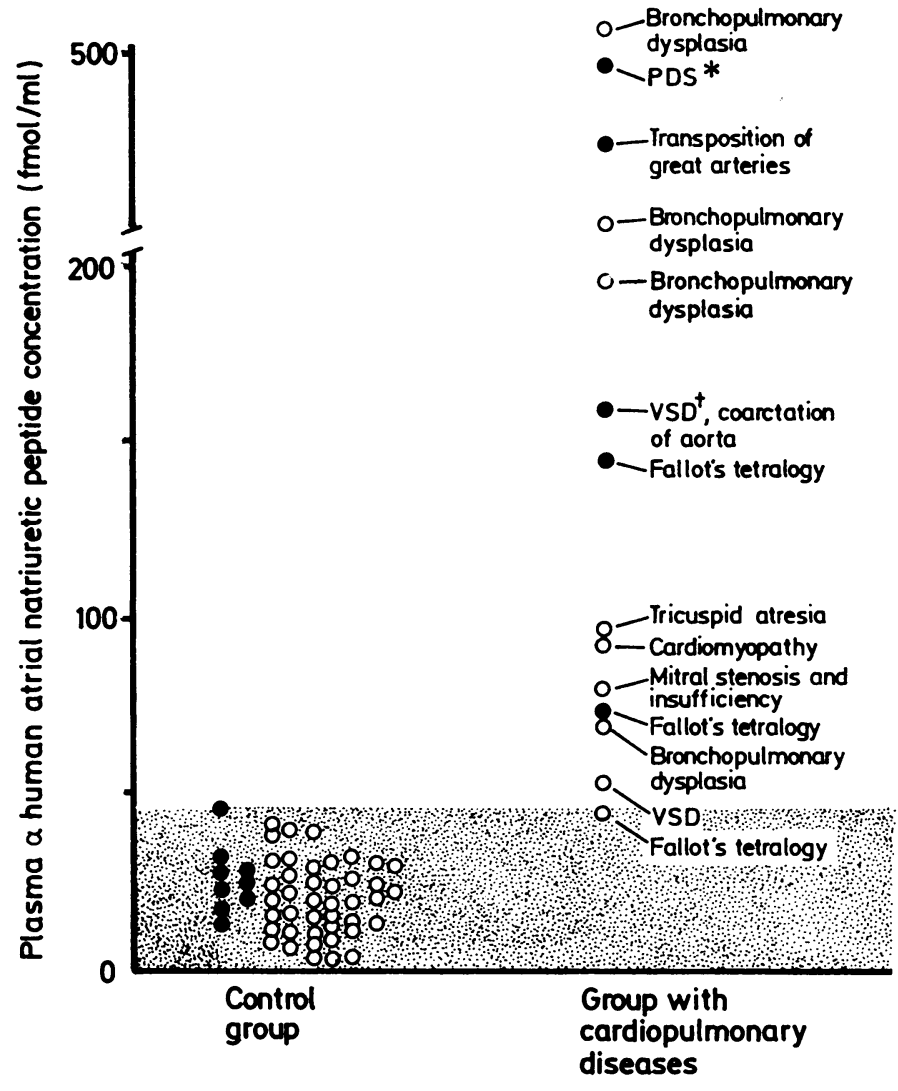

Plasma alpha human atrial natriuretic peptide concentrations in children with congenital heart diseases and bronchopulmonary dysplasia without disorders of body fluids or electrolytes compared with those in children without cardiac and pulmonary diseases. Filled circles are children aged $<1$ year.

$\star \mathrm{PDS}=$ patent ductus arteriosus.

+VSD = ventricular septal defect.

our study may be sufficiently high to elicit cardiovascular and renal effects. This is supported by Tikkanen et al, who reported that during infusions of $\alpha$ human atrial natriuretic peptide plasma concentrations above $33 \mathrm{fmol} / \mathrm{ml}$ $(100 \mathrm{pg} / \mathrm{ml})$ were associated with a slight decrease in blood pressure and a definite natriuresis and diuresis. ${ }^{5}$ The same authors showed that plasma $\alpha$ atrial human natriuretic peptide concentration was raised in patients with congestive heart failure.

This observation together with our finding of raised concentrations in children with cardiopulmonary disease are consistent with the idea that increased preload resulting in atrial stretch stimulates the release of $\alpha$ human atrial natriuretic peptide into the circulation. Moreover, the data suggest that the hormone might be valuable as a non-invasive humoral marker in the diagnosis of various cardiac and pulmonary diseases and in evaluating responses to treatment.

Needleman P, Adams SP, Cole BR, et al. Atriopeptins as cardiac hormones. Hypertensio 1985;7:469-82.

2 Lang RE, Thoelken H, Ganten D, Luft FC, Ruskoaho H, Unger T. Atrial natriuretic factor-a circulating hormone stimulated by volume loading. Nature 1985;314:264-6.

3 Rasher W, Tulassay T, Lang RE. Atrial natriuretic peptide in plasma of volume overloaded children with chronic renal failure. Lancet 1985 ;ii:303-5.

4 Richards AM, Ikram H, Yandle TG, Nicholls MG, Webster I, Espiner EA. Renal, haemodynamic and hormonal effects of human alpha atrial natriuretic peptide in healthy volunteers. Lancet 1985; i:545-9.

5 Tikkanen I, Fyhrquist F, Metsarinne K, Leidenius R. Plasma atrial natriuretic peptide in cardiac disease and during infusion in healthy volunteers. Lancet 1985;ii:66-9.

(Accepted 25 September 1985)

German Institute for High Blood Pressure Research and Department of Pharmacology, 6900 Heidelberg, West Germany

R E LANG, MD, associate professor of pharmacology

T UNGER, MD, associate professor of pharmacology

D GANTEN, MD, professor of pharmacology

Haunersches Kinderspital, University of Munich

J WEIL, MD, associate professor of paediatrics

F BIDLINGMAIER, MD, professor of paediatrics

D DOHLEMANN, MD, professor of paediatrics

Correspondence to: Dr Lang. 